\title{
Jesus' Intitulation of God as Abba: Its Sources and Impact on the Idea of the Fatherhood of God in the New Testament
}

\author{
STEFAN SZYMIK \\ The John Paul II Catholic University of Lublin \\ stesz@kul.pl, ORCID: 0000-0001-9544-2976
}

\begin{abstract}
In the article, the author discusses Jesus' intitulation of God as Abba and its impact on the idea of God's fatherhood in the New Testament writings. Responding to the recent criticism of J. Jeremias's theses (cf. B. Chilton, M.R. D'Angelo), he tries to show that without the initial source, which was Jesus of Nazareth and his public teaching, the dynamic expansion of the idea of God's fatherhood in the New Testament would not be possible. After a brief presentation of J. Jeremias's ground-breaking opinion on Jesus' filial relation to God as Father, encapsulated in the "Abba, Father" cry (Mk 14:36), a second section analyses the texts of the Hebrew Bible and Second Temple Judaism that explore the theological idea of God as Father. The third part focuses on the NT witnesses to God's fatherhood, i.e. God both as the

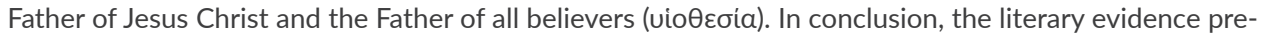
served in the NT writings and rational arguments point to Jesus of Nazareth as the source and starting point of the NT idea of God's fatherhood. Jeremias's study is still valid, and the address "Abba-Father" uttered by the historical Jesus remains the most concise and fullest expression of his filial relation to God.
\end{abstract}

Keywords: Abba, Joachim Jeremias, God the Father, the fatherhood of God, the Son of God, adoption

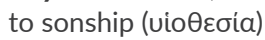

The ground-breaking opinion voiced by Joachim Jeremias on the theme of Jesus' filial relation to God the Father, captured concisely in the address "Abba, Father" (Mark 14:36), found a huge resonance in biblical literature and provoked discussions that have continued to this day. ${ }^{1}$

1 An extensive, critical discussion regarding Joachim Jeremias's theses has recently been presented by Georg Schelbert (Abba Vater, esp. 23-34), who limited his study to the analysis of Hebrew and Aramaic texts, with the omission of Greek texts (he obviously takes into account Abba in Mark, Galatians and Romans). He concludes, "Die Vater-Anrede und die Bezeichnung Gottes vor allem als Vater ist die Eigenart und Besonderheit der Gottesbeziehung und Gottesverkündigung Jesu” (p. 390); cf. his earlier publications including Schelbert, "Sprachgeschichtliches zu Abba," 395-447; Schelbert, "Abba, Vater! Stand der Frage," 259-281; cf. Ruckstuhl, “Abba, Vater!” 515-525; Wilk, “«Vater...». Zur Bedeutung der Anrede,” 201-203; Puech, "Dieu le Père," 287-310; Ternyák, “Abbaa nel pensiero," 29-60. Csaba Ternyák discusses Jeremias's publications concerning Abba and the more important Old Testament and Judaic references to God's fatherhood in order to present the teaching of Jesus of Nazareth, for whom the term Abba was - according to Ternyák - the most fundamental title for God as well as his prayer of invocation. Ternyák supports 
The particular components of his analyses have either been enthusiastically received and repeated, or corrected and clarified - which mainly concerns the Aramaic term $a b b a$ and its use in the first century of the Christian era - or even questioned and rejected as erroneous. According to some recent opinions, the intitulation "Abba - Father" has not been anything new or original, and additionally, its presence in the teaching of Jesus of Nazareth has been denied. Thus it cannot be given a normative value for contemporary theology and liturgy. ${ }^{2}$ In the related approaches, Jesus' Aramaic call Abba appears in the context of anti-Jewish polemics ${ }^{3}$ and liberal feminist exegesis. ${ }^{4}$

While studies supplementing selected aspects of Jeremias's argumentation are correct and valuable, there are justified doubts as to denying Jesus any originality in his teaching on God as Abba, and even his use of this title. ${ }^{5}$ Unquestionably, it is worth getting to know and verify the above-mentioned allegations, especially the arguments for the minimalist approach. In this context, the basic aim of resuming the topic is to show that without the first source, which was Jesus of Nazareth and his public teaching, a dynamic development of the theological thought regarding God as Jesus' Father and our Father, an idea that is present throughout the New Testament, would not have been probable. It is worth adding that analogous theses have appeared in some publications (among others, J.D.G. Dunn and M. Thompson).

the validity of Jeremias's theses on the term $A b b a$, and moreover, he stresses the importance of this term for the NT Christology (pp. 56-60). See further Thompson, The Promise of the Father, esp. 21-34, including a theological evaluation of Jeremias's theses; also Zimmermann, Die Namen des Vaters, 42-48.

2 Chilton, "Abba," 42; identical thesis: Chilton, "God as 'Father," 169: "That comparison leads to a simple finding: Matthew's Jesus does not say anything radically new about God in calling him 'father"' According to Bruce Chilton, the Gospel of St Matthew would be representative for all the canonical gospels. A more radical view is expressed by Mary Rose D'Angelo (“Theology in Mark and Q," 173): "On the basis of Mark and Q, it cannot be shown that either the expression $a b b a$ or the divine title 'father' was used by Jesus [...]. Nor, on the other hand, can the possibility that Jesus addressed God as father be excluded; Jesus was a Jew who is likely to have drawn on the tradition in prayer," and further on p. 174: "Thus Jesus' possible use of $a b b a$ or 'father' cannot be used to defend the normative nature and primacy of 'father' for twentieth-century theology and liturgy or to endow these words with special meaning"; cf. D'Angelo, "ABBA and 'Father," 616, 630.

3 Cf. Gnadt, "Abba isn't Daddy," 117-125; see a historical outline of the discussion in Chilton, "God as 'Father", 153-155.

4 Gnadt, "Abba isn't Daddy," 115-117, 125-131; D'Angelo, "ABBA and 'Father," 630: "But the use of 'father' in the NT cannot be ignored; it is important not only to diversify language and imagery for God but also to attend to the patriarchal and imperial horizons within which Christianity was born and has lived, and to continue to ask how they have limited our visions of the divine"; see also Thompson, The Promise of the Father, 1-20; Zimmermann, Die Namen des Vaters, 47.

5 D’Angelo, "ABBA and 'Father," 616: "Abba cannot be shown to have been unique to Jesus, characteristic of Jesus, or even to have been used by Jesus." See the factual discussion of this opinion in Thompson, The Promise of the Father, 23-25, 58-59, concluding: "D'Angelo's conclusion stands diametrically opposed to the research of Jeremias and those who argued that Jesus' use of the Aramaic abba for God gave rise to the church's subsequent practice" (p. 59). 


\section{A Brief Presentation of Joachim Jeremias's Opinion}

Jeremias's position regarding Jesus' filial relation to God as Father was based on several premises. ${ }^{6}$ The major premise was that the particular sources recorded in the canonical gospels (Q, Mark, Matthean and Lucan special material, also John) are totally consistent in the fact that Jesus of Nazareth called God his Father. ${ }^{7}$ As Jeremias stated, in the light of the preserved Jewish texts of that period, Jesus' attitude was extraordinary and unique since individual Jews did not address God as Father; on the other hand, the use the collective "our Father" was attested. ${ }^{8}$ Further, the occurrence of several different Greek forms in the canonical Gospels, in the nominative (o $\pi \alpha \tau \eta \dot{\rho}$ ) and the vocative ( $\pi \alpha \dot{\tau} \tau \rho)$ ), also with a possessive pronoun ( $\pi \alpha \tau \eta \dot{\rho} \mu$ ov), allows us to claim that they were rooted in the Aramaic term אבא (transcribed $\alpha \beta \beta \alpha$ as a status determinatus or emphaticus). Using this address, Jesus expressed his close relation to God, which was very unique among the Palestine Jews of those days (an exception is the Targum of Ps 89:27; cf. Mal 2:10). ${ }^{9}$ Moreover, Jesus spoke to God as a child speaks to its earthy father, with confidence and love as well as respect and obedience. Jesus' exceptional relation to God the Father gave rise to the NT Christology of the Son of God (cf. Matt 11:27; Luke 10:12). Finally, it should be recalled and emphasised that the main goal of Jeremias's analyses in confrontation with the morpho-critical school was to reach the historical Jesus and ipsissima vox Jesu. ${ }^{10}$

The argumentation proposed by Jeremias was met with vivid reactions and resulted in rich literature. In his later publications Jeremias corrected the oversimplified translation of the expression as "dad" or "daddy." The philological problems related to this Aramaic term have also been explored by other authors. ${ }^{11}$

6 See Jeremias, Neutestamentliche Theologie, 67-73; Jeremias, "Abba," 15-67; Jeremias returned to this question six times, modifying some of his theses; cf. Schelbert, Abba Vater, 19-23, 400-401; Ternyák, “Abba' nel pensiero," 29-31.

7 See Mark (14:36), Q (Mt 6:9 = Luke 11:2; Matt 11:25-27 = Luke 10:21-22), Matthew's own material (26:42) and Luke's own material (23:34.46), many passages in the Gospel of John. According to Jeremias, there are 16 different logia of Jesus in which he addressed God "my Father"; see Jeremias, "Abba," 56. The exception is Jesus' words uttered on the cross (Mark 15:34; par. Matt 27:46; cf. Ps 22:2).

8 Jeremias, Neutestamentliche Theologie, 70: "Das heißt: in der Literatur des antiken palästinischen Judentums ist die individuelle Gottesanrede "mein Vater « bisher nicht nachgewiesen"; Jeremias, "Abba," 33; he continues: "Dieses "mein Vater « Jesu hat in der rabbinischen Literatur keine Entsprechung" (p. 55).

9 Jeremias, Neutestamentliche Theologie, 71: "Wir stehen mit alledem vor einem Tatbestand von fundamentaler Bedeutung: während wir keinen einzigen Beleg dafür besitzen, daß Gott im Judentum mit 'Abba angeredet worden wäre, hat Jesus Gott stets in seinen Gebeten so angeredet...”; on the same page the German scholar explains why he excluded Ps 89:27 and Mal 2:10; cf. Jeremias, "Abba," 59-62. The Greek texts as textual witnesses were omitted by Jeremias because of their provenance from the Hellenistic diaspora. See Jeremias, "Abba," 19, 31 and 59; Jeremias, Neutestamentliche Theologie, 69; cf. Ternyák, “Abba’ nel pensiero," 39.

10 Jeremias, "Abba," 59; Jeremias, Neutestamentliche Theologie, 72.

11 See Jeremias, Neutestamentliche Theologie, 73; cf. Schelbert, Abba Vater, 17-23; Barr, "ABBĀ isn't 'DADDY," 28-46, concludes: "But in any case, it was not a childish expression comparable with 'Daddy': 


\section{The Idea of God as Father in the Hebrew Bible and Second Temple Judaism}

Calling God Yahweh "Father" was known in the Old Testament although it was rarely used, and the term was one of many titles of God. ${ }^{12}$ Yahweh as the maker and father of Israel is presented in the category of the nation being chosen, called and covenanted (Ps 89:27; Prov 3:12), as the One who stands by his chosen "son" like an earthy father would do (see Exod 4:22; Num 11:12; Isa 1:2; Hos 11:1-9). Yahweh made Israel (Deut 32:6; cf. 32:18) and so he is "our father" (אבינו In Isa 63:16; 64:7) and "protector" (cf. Ps 68:6; 103:13;), and "one father" (Mal 2:10; cf. 1:6). In turn, Israel was established as the firstborn of Yahweh, often unfaithful (Jer 3:4.19; 31:9; cf. 2:27; 31:20). The thought of God as the Father of the people was also preserved in theophoric names with the particle אב, for example Eliab (Num 1:9), Abiel (1 Sam 9:1), Abijah (1 Chr 7:8) and many others. ${ }^{13}$

The biblical depiction of God as Father refers to the image of an Israelite family, which was close to the inspired authors, in which the father had a special place as their parent, provider and educator, but also their guardian and protector. When referring to God Yahweh, the term "father" was primarily an element of a biblical image or figurative, and only exceptionally it served as a title or invocation, usually in the collective cry "Our Father." 14

The idea of the Fatherhood of God also appears in the deuterocanonical books of the Old Testament, which are to be dated to the period before the Christian era (2nd-1st centuries BC). These texts are important because they include several

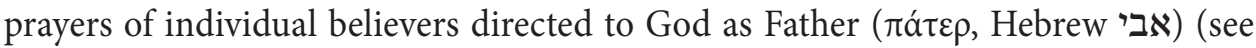
Sir 23:1.4; 51:10 hebr.; Wis 14:3; cf. 2:16.18; 11:10; Tob 13:4). Moreover, it cannot be ruled out that at least some of the quoted texts reflect the religiosity of Palestinian

it was more a solemn, responsible, adult address to a Father"; cf. Fitzmyer, "ABBA and Jesus' Relation to God," 14-38; Chilton, "Abba," 40; Thompson, The Promise of the Father, 27.

12 The Hebrew term refers to God only 15 times out of the total 1,213 cases in the Hebrew Bible. However, the number of OT texts referring to fatherhood (of God) and sonship (of Israel) is much bigger.

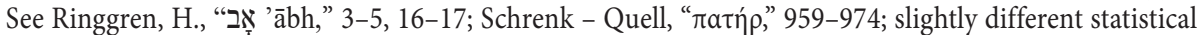

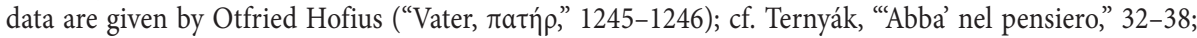
Thompson, The Promise of the Father, 35-55; Zimmermann, Die Namen des Vaters, 48-52; Szymik, "Biblijna idea Boga jako Ojca," 3-26.

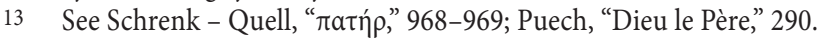

14 See the discussions: Schenker, "Gott als Vater - Söhne Gottes," 3-55; cf. Chrostowski, "Bóg jako Ojciec," 205-208; Szymik, "Biblijno-religijny kontekst Jezusowej intytulacji," 649-652. Cf. also Rupprecht, "Zu Herkunft und Alter der Vater-Anrede," 347-355, who analyses the text of 1 Chr 29:10 ("Blessed are you, o Lord, the God of Israel our father, for ever and ever") and proposes to read it as: "O Lord, the God of Israel, our Father for ever and ever." This lesson could be confirmed by the analogous texts of Isa 63:16;

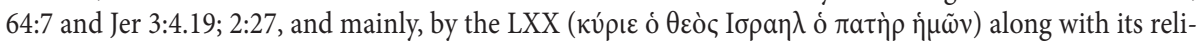
gious and liturgical context. 
Jews. Accordingly, calling God "our Father" is attested in the Egyptian diaspora of the 2nd century BC..$^{15}$

The OT citations constitute the primary context for statements about God the Father in the time of Jesus of Nazareth. Obviously, the reception of these texts in Judaism, which was contemporary to Jesus and early Christianity, is essential for the issue under consideration. The witnesses of this reception (apart from the deuterocanonical books) have been preserved in rich non-biblical literature, in the writings from Qumran and in the Aramaic translations of the biblical texts (Targumim). ${ }^{16}$ Jewish religiosity and piety are confirmed in non-biblical literature, the authors of which were inspired by the contents of the canonical books. The idea of God as 'father' appears in at least a few texts written at the turn of the epochs (dating from the third century BC to the first century of the Christian era). This idea has survived in the Greek version of the Testament of Levi (T.Levi 17:1-2; cf. 18:6). ${ }^{17}$ A comparable record can be found in the Testament of Abraham, which must have been created in Egypt, too (T.Ab. 6:6; 20:12). The apocryphal Greek Testament of Job comes from a similar period and milieu. In one of the later copies of this document, the title "father" is referred to God several times (T.Job 33:3.9; 40:2; 47:11?; cf. 50:3). Yet, these texts lack a direct individual address to God as Father. Moreover, they show God as distant and sublime, dwelling in his magnificent heavenly glory. ${ }^{18}$ Our last textual witness should be the apocryphal Third Book of the Maccabees, which includes this motive, appearing also in a form of prayer. God is almighty and merciful "Father"

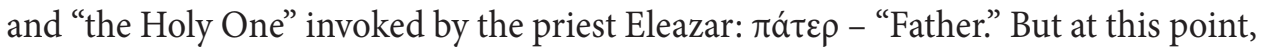
we are dealing with a priestly intercessory prayer for the whole nation (3 Macc. 6:3.8; cf. $2: 21 ; 5: 7){ }^{19}$

15 See especially Puech, "Dieu le Père," 290-295; he discusses the textual Hebrew and Greek variants and reconstructs their original texts. In his conclusions to the Book of Sirach, he writes: "une conclusion s'impose avec force: l'affirmation plusieurs fois répétée dans un contexte de prière ou de sagesse dans le Siracide (manuscrit hébreu ou substrat hébraïque) ne doit rien a une influence grecque du judaïsme égyptien, mais le sage palestinien affirme clairement la paternité de Dieu qui aime et prend soin du juste juif, son fils" (p. 294).

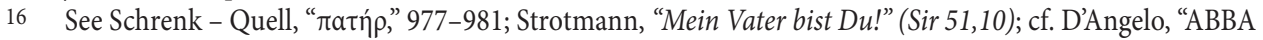
and 'Father", 617-622; Zimmermann, Die Namen des Vaters, 52-64; Szymik, "Biblijno-religijny kontekst Jezusowej intytulacji," 652-655. However, here we should again consult Puech, "Dieu le Père," 296-303, analysing numerous apocryphal texts, including the four variants of the Book of Jubilees, which was also confirmed partly in Qumran (Jub. 1:24-25.28; 19:29).

17 The Aramaic fragment of this document, found in the Cairo geniza, contains abba (אבא) referring to an earthy father: Grelot, "Une mention inaperçue de «ABBA»," 101-108; see an extensive analysis in: Schelbert, Abba Vater, 43-47; cf. Beyer, Die aramäischen Texte, 189, 196-197, 445 and 503.

18 Puech, "Dieu le Père," 301-302; cf. Chilton, "God as 'Father," 160-162, who attributed a profound meaning to this document in his critical discourse with Jeremias's theses (see below); cf. Spittler, "Testament of Job," 829-868.

19 Wojciechowski, Apokryfy $z$ Biblii greckiej, 83 with note 225, writes that the address "Father," repeated in this prayer (6:8), indicates that in the NT speaking about God as Father was not a novelty in Judaism 
Furthermore, the religious idea of divine fatherhood is also testified in several texts from Qumran where we have the Hebrew אבי אבא was not attested there. In some texts calling God "father," the term occurs in metaphorical clauses in which God is compared to an earthy father (1QH; 4Q369). Further, we can find two cases of the address - אבי - "my Father" in prayers of invocation directed straight to God (4Q372 frag. 1,16: "My father and my God"; 4Q460: frag. 4,5-6: "my father and my lord"). However, many scholars regard these texts as earlier (pre-Qumranic) and as the evidence of the religious influence of early Judaism on the community at Qumran (ca. the 3rd century BC). ${ }^{20}$

The Aramaic translators of the Hebrew Bible usually used אבא as the Aramaic equivalent of אב predominantly in metaphorical texts and descriptions (Deut 32:6; Ps 103[102]:13; Job 38:28; Prov 3:12; cf. Mal 1:6). They exceptionally used it in the texts straightforwardly calling God "Father" (Ps 89:27; Mal 2:10). ${ }^{21}$ In a few texts, the Hebrew term רבון had the Aramaic equivalent ("Lord, Master") (Jer 3:4.19; cf. Jer 2:27 - אבונא) or was softened by the use of the figurative image of a father who pities his children (Isa 63:16; 64:7). ${ }^{22}$ In Georg Schelbert's opinion, the Aramaic appears only in two cases of the Hebrew אבי (Ps 89:27; Targum of Job 34:36), but here the important thing is the problematic dating of these Palestinian Targumim, which seem to be considerably later than the NT writings. ${ }^{23}$

although its context and understanding by Jesus and his disciples were different because Eleazar's prayer predominantly referred to God's power.

20 Schuller, "4Q372 1," 349-376; Schuller, “The Psalm of 4Q372 1," 67-79; Barr, "ABBĀ isn't 'DADDY”, 43; Mitchell, "A Dying and Rising," 188. Three other texts (4Q504 frag. 1-2, col. 3,1; 4Q502 frag. 39,3; 4Q511 frag. 27,1) are cited and discussed by Puech, "Dieu le Père," 303-306, 309. See Fabry, "אָר̄ā," 8-9: "In der Benennung Gottes als »Vater" unterscheidet sich Qumran nicht vom zeitgenössischen Judentum, geht allerdings mit dieser Bezeichnung äußerst sparsam um"; so Doering, "God as Father," 125-130, who concludes: "The two examples of the direct invocation 'my father' provide valuable insights into what might have been a more widespread form of addressing God. They continue enunciations like those in Ps 89:27 and Sir 51:10 and provide a Palestinian, Hebrew counterpart to the invocation 'father' in Greek Jewish texts," and further: "In sum, God's 'fatherhood' is not a major theme in the texts from Qumran. It needs to be related to other, quantitatively more prevalent modes of speaking about God" (p. 132).

21 These translators' activities are well illustrated in the texts in which God is the "nursing father" of the kings of Israel because he is shown in a metaphorical way (Targum of 2 Sam 7:14 כאבר לאביבת; Ps 2:7 חביב כבר לאבא את לי) 1 Chr 17:13; 22:10; 28:6 always as כאבא).

22 Besides the cited works, my compilations and analyses of the Aramaic translations are based on the texts of BibleWorks 10.0 (Custom licence).

23 Schelbert, Abba Vater, 121-124, see p. 381: "Die Anrede »mein Vater « an Gott ist in der hebräischen Bibel äusserst selten. Daher auch in der aramäischen Übersetzung der Bibel." As he adds, this way of speaking about God will be continued in the following ages (Tanaites, Talmudists), stating: "In den Texten steht fast immer nicht eine Einzelgestalt im Vordergrund, sondern das Kollektiv des Volkes. Daher findet sich sonst nur "ihr, euer Vater im Himmel«". These statements are partially supplemented by Chilton's earlier analyses, e.g. Targumim of Gen 21:33; Num 20:21; Deut 32:6; 33:24; he also acknowledges the difficulties resulting from their dating; cf. Chilton, "God as 'Father", 155-160, and concludes: "the Targumim reflect a rich conceptual development of God as 'father', and do so in a way that makes it impossible immediately to characterize what the usage of the first century might have been" (p. 160); so Hengel, "Abba, Maranatha, Hosanna," 147 and notes 13-15; Puech, "Dieu le Père," 308. 
In sum, speaking about God as Father was not something unique in the biblical tradition although it was not a dominant theme; in fact, it was quite the opposite. Moreover, the divine fatherhood of Israel was understood in terms of the nation's special choice and establishment, and the biblical authors most frequently resorted to comparisons and metaphors. ${ }^{24}$ The motive of divine fatherhood also appears in Jewish religious literature, contemporary to nascent Christianity, especially in the Hellenistic (mainly Egyptian) diaspora; hence the influence of the Greek milieu cannot be ruled out. The intitulation "Father" was used by the Jewish communities in a collective sense, but it occurs in individuals' prayers, their personal pleas and calls for help as well. ${ }^{25}$ On the other hand, some Aramaic apocryphal texts and the Targumim provide analogies to Jesus' intitulation “Abba, Father" (cf. Targum of Ps 89:27), which was attested at the earliest in Christian documents (the dating of the Targumim is uncertain).

\section{God as Father in the Teaching of Jesus and the Primitive Church}

The earliest, convincingly dated, New Testament writings are the Epistles of Saint Paul, from which we have the Aramaic and Greek forms of the term: $\alpha \beta \beta \alpha$ ó $\pi \alpha \tau \eta ́ p$. The Gospel of Saint Mark, which preserved the same collocation, was written several years later (Gal 4:6; Rom 8:15; cf. Mark 14:36) ${ }^{26}$ Nevertheless, the first source of the NT oracle of God as Father is Jesus of Nazareth since against some separate opinions (cf. M.R. D’Angelo) one can speak of a consistent witness to all the Christian documents in question and also of the fulfilment of the criterion of a multiple tradition (Mark, Q and Paul). ${ }^{27}$

24 Chrostowski, "Bóg jako Ojciec," 207, confirms that in the whole Bible, the concept of God as Father was not a central motive, but only one of many ways to understand and present the covenant between God and the Israelites. See also Ringgren, "אב 'ābh," 17; Fabry, "אב ’āb," 2; Puech, "Dieu le Père," 308.

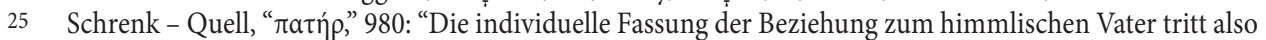
keineswegs erst bei Jesus auf”; Rupprecht, "Zu Herkunft und Alter der Vater-Anrede," 355: "Für uns wird deutlicher erkennbar, daß Jesus mit der von ihm bevorzugten Anrede Gottes als Vater in der Tradition einer weit zurückliegenden Erbfolge steht"; so Barr, "ABBĀ isn't 'DADDY," 46-47. D’Angelo, "ABBA and 'Father," 614-616; Zimmermann, Die Namen des Vaters, 47-48. Thus, it is worth noting that Gustaf Dalman (The Words of Jesus Considered, 189) formulated this opinion as early as in 1902 and Jeremias must have known it: "It was therefore nothing novel when the fatherly relation of God was also applied within the Jewish community to the individual".

26 Schelbert, Abba Vater, 54, dates the letters respectively to 54-55 AD (Galatians) and 56-58 (Romans); and the second Gospel (Mark) to 68-70 AD.

27 D'Angelo, "ABBA and 'Father," 614-615, is wrong stating: "Thus the attribution of abba to Jesus does not have multiple attestation." Even if the witness of Q were undermined, there would be the texts of Mark and Paul (see below note 41); cf. the apt analysis in Thompson, The Promise of the Father, 59-63 (the criterion of multiple attestation and the criterion of dissimilarity); see also Zimmermann, Die Namen des Vaters, 76 and note 209. 
The second canonical Gospel, based on Peter's catechesis, confirms the term "father" in relation to God four times, including the relationship of the Son to the Father in three texts (Mark 8:38: the Son of Man; also 13:32 and 14:36) and once in the disciples' relation to the Father (Mark 11:25: ó $\pi \alpha \tau i ̀ \rho ~ v i \mu \tilde{\omega} v)$. The last logion about forgiving your neighbour as a condition of the disciples' good prayer has a parallel in the first Gospel (Matt 6:14). Similarly, the announcement of the Parousia, whose day or hour no one knows, neither the Son (o vióc), but only the Father (ó $\pi \alpha \tau i ́ p)$ (Mark 13:32), is also preserved in the Gospel of Matthew (Matt 24:36). The essential thing is the definite use of both terms that reveal the dignity of Jesus who was aware of his divine Sonship although the Christological significance of the logion has been debated. ${ }^{28}$ The same, unique relationship of the Son with the Father was depicted in the scene of Jesus' agony when he prayed "Abba, Father" (Mark 14:32-42). Those authors who claim that Jesus could not have prayed in the way transmitted by Mark might be right since the bilingual phrase $\alpha \beta \beta \alpha$ o $\pi \alpha \tau \eta ́ \rho$ was a prayer of the Christian communities that are known to have existed outside Palestine (second Sitz im Leben). ${ }^{29}$ Redacting the Gospel in a new historical-religious context, most likely in Rome around 68-70 AD, the second Evangelist used the form that was common among believers (cf. Rom 8:15). These statements do not change the fundamental fact that in his final hours Jesus prayed to God as his Father using Abba (cf. Matt 26:39.42; Luke 22:29.42). ${ }^{30}$ During the agony, and similarly in the whole second Gospel, the exceptional dignity of Jesus as the Son of God comes to the fore. The Christological oracle is the foundation of the second Gospel, and at the same time, it is a proper fulfilment of the message of God as Jesus' Father, preserved by Mark (cf. Mark 1:1.11; 9:7; 15:39). ${ }^{31}$

At this point, it is worth making a digression about the historical credibility of the Gospel accounts of the Passion and Death of Jesus, and similarly to emphasise

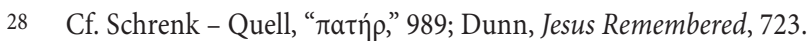

29 The Greek transcription proves that in the case of $\alpha \beta \beta a$ (status determinatus or emphaticus, reduplication of the consonant bet: אבבא) we are dealing with a vocative: the Aramaic Abba means "Father!" The nominative o $\pi \alpha \tau$ ́n $\rho$ should be translated in a similar way - as the vocative "Father!" This grammatical change (nominative instead of a vocative) is attested in Greek koine, and a perfect illustration of this phenomenon is the priestly prayer of Jesus (John 17). See Schelbert, Abba Vater, 54. It is worth noting that the Greek

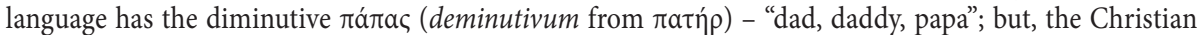
community did not use this word to render Jesus' $\alpha \beta \beta \alpha$; see Schelbert, Abba Vater, 54, 63; cf. D’Angelo, "ABBA and 'Father", 615.

30 Schelbert, Abba Vater, 60: "Schliesslich geht die aramäische abba-Anrede - ohne die griechische Ubersetzung - auf Jesus selbst, Ende der 20-er, Anfang der 30-er Jahre zurück." Cf. the interestingly documented thesis of Michael P. Theophilos ("The Roman Connection: Paul and Mark," 45-67); see also Theobald, "Die Passion Jesu bei Paulus und Markus," 243-282.

31 Out of the 35 usages of the term vióc in Mark as many as 26 refer exactly to Jesus as the Son or occur with an object (including "Son of Man" used 14 times). Moreover, several other texts have a clear Christological sense: the parable of the tenants (Mark 12:1-9; cf. Matt 21:33-41; Luke 20:9-16) or the cry of Bartimaeus "Son of David" (Mark 10:47-48; cf. 12:35-37). For the topic of Jesus as the Son of God see Dunn, Jesus Remembered, 720-723. 
the historical value of the canonical Gospels, which has been questioned. The historical core of Mark's message does not exclude, but even assumes the presence of parenetic and didactic elements in the scene of Jesus' agony (instructing the disciples on the need to keep alert and pray)..$^{32}$ Likewise, the historicity of the events recorded in the Gospel accounts of Jesus' passion and death should not be debated. ${ }^{33}$

Besides the Gospel of Mark, the second early source of our knowledge concerning the unique relationship between Jesus and God as Father is the hypothetical source Q, which has preserved two witnesses: the logion of the revelation of the Father and the Son (Matt 11:25-27; Luke 10:21-22) and the prayer "Our Father" (Matt 6:9-13; Luke 11:2-4). ${ }^{34}$ The Matthean logion must have preserved Jesus' saying in its original form, while Luke added two redactional elements to it. ${ }^{35}$ The logion can be logically divided into two parts, which were probably transmitted independently of each other: the praise of the Father by the Son (Matt 11:25-26; Luke 10:21) and the revelation of the mystery of the Father and the Son (Matt 11:27; Luke 10:22). Bearing in mind the purpose of our analysis, several components of this logion deserve attention. Firstly, in such a short passage, God is called "Father" as many times as five (ó $\pi \alpha \tau \eta ́ \rho$

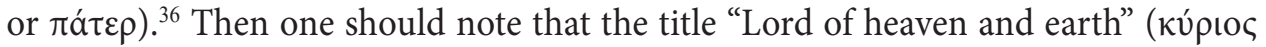

32 Cf. Sim, "The Family of Jesus," 92-93: "But the problem with these sorts of explanations is that the disciples are not simply fictional characters in a fictional story. They were real people who would have been familiar, at least by reputation, to the intended readers of Mark's narrative"; cf. also Dunn, Jesus Remembered, 714, with note 40.

33 A substantive discussion of the tradition and redaction of Jesus' in Gethsemane (Mark 14:36), source Q and Paul's credibility can be found in Dunn, Jesus Remembered, 708-724, esp. 713-716. The British theologian writes on page 783: "In short, we can be fairly confident that the tradition of Jesus' final days was already being recalled and reflected on from the very earliest days of communal gatherings of Jesus' followers after Easter 30 CE”; cf. also Dunn, The Theology of Paul, 189-195, esp. 193.

Voices in defence of the historical value of the Gospels and their adequate interpretation have been heard many times recently. See Pontificia Commissione Biblica, Ispirazione e verità, No. 84: "Va anche ritenuto improprio l'assunto che teorizza la discontinuità fra Gesù e le tradizioni che lo attestano, oppure la mancanza di interesse o l'incapacità di presentarlo in modo adeguato. I Vangeli stabiliscono dunque un collegamento veritiero con il vero Gesù"; Keener, "Luke-Acts and the Historical Jesus," 623: "In view of such factors as those surveyed above, I believe that there is reason to suppose that Luke not only has interest in retelling historical information, but also that much of the information to which he had access ultimately stems from fundamentally reliable and eyewitness sources"; Janusz Kręcidło ("Ewangelie jako prawdziwe świadectwo," 187) says that the key to understand the Gospels as true witnesses to the Incarnated Word is to treat them as a material record transmitted by trustworthy witnesses.

34 Cf. the right opinion of James.D.G. Dunn (Jesus Remembered, 712): "Nevertheless, it is clear that the Q tradition retains a vivid memory of Jesus praying to God as Father." Document Q was created in Galilee between 40 and $70 \mathrm{AD}$ (dating uncertain); see the discussion in Dunn, Jesus Remembered, 159-160; Paciorek, Q - Ewangelia Galilejska, 169-174.

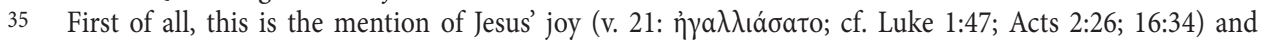
then the mention of the Holy Spirit (Luke 1:15.35; 3:21; 4:1.18, etc.); see Kudasiewicz, "Jezus Chrystus," 432-438; cf. Jeremias, "Abba," 47-54; Ternyák, "'Abba’ nel pensiero," 48-50; Paciorek, Q - Ewangelia Galilejska, 291-294; Dunn, Jesus Remembered, 712-713, 718-720.

36 It should be assumed that Jesus spoke in Aramaic and so he must have used the Aramaic term $\alpha \beta \beta \alpha$. See Dalman, The Words of Jesus Considered, 191-192; Jeremias, Neutestamentliche Theologie, 70; cf. Schelbert, Abba Vater, 34, 63-64; Barr, "'ABBĀ isn't 'DADDY", 44; Zimmermann, Die Namen des Vaters, 88-90. 


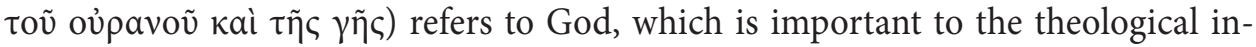
terpretation of the title "Father." Since according to Jesus, the Father is at the same time "Lord of heaven and earth." Jesus resorted to the formula that conveys the same

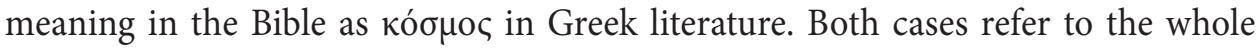
created world. God is the Lord of both parts of the created world and is the Lord of everything that exists. Therefore, "Father $(A b b a)$ " used in the prayer in the Garden of Gethsemane and here cannot be reduced to the infantile and childish "dad, daddy" because God the Father is both the Lord of the created world and the Lord of human destinies. God the Father is distant and close, worthy of the highest respect, but also trustworthy. In addition, it should be emphasised that the text contains a few verbs

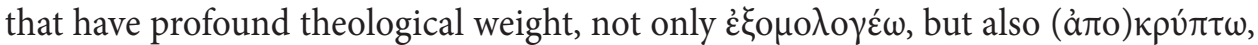

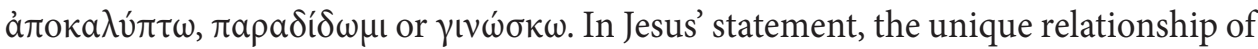
closeness between the Father and the Son comes to the fore, and the text also reveals that the Son has full knowledge of the Father and full access to him. These Christological contents are known only from the fourth Gospel (John 10:15; cf. 10:30). ${ }^{37}$

In the case of the prayer "Our Father" (Matt 6:9-13; Luke 11:2-4), the history of its tradition and redaction was undoubtedly different. Since it should be assumed that here it was Matthew who redacted the prayer, adding some new elements, while the shorter version of the prayer preserved by Luke is closer to its original version. If this supposition is correct (we remain within the sphere of hypotheses), ${ }^{38}$ the introductory invocation originally had a simpler form: "Father" (the Greek $\pi \dot{\alpha} \tau \varepsilon \rho$, hypothetically the Aramaic $\alpha \beta \beta \alpha$ ). Those who prayed it could have been an individual disciple or a group of disciples. However, regardless of that, "Our Father" confirms the central place of the idea of God's fatherhood in the life and teaching of Jesus Christ. ${ }^{39}$

Now the key element is the interpretation of the contents recorded in the Epistles of Saint Paul. Two points should deserve our attention. As it has already been observed, the Apostle of the Nations transmitted the bilingual invocation "Abba! Father!" in his writings (Gal 4:6; Rom 8:15). Therefore, we can conclude that the invocation was known not only to Judeo-Christians, but also to the Christians of pagan back-

37 Consequently, Chilton's juxtaposition of Jesus' logion of the revelation, which conveys rich theological contents, with the brief and enigmatic words from the Testament of Job is not convincing at all: "And

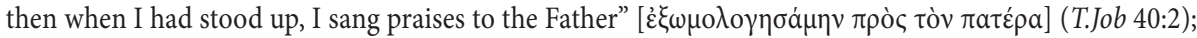
summing up his concept Chilton ("Abba," 41) writes, "Similarly, Jesus' statements of the father's revelation in Matthew are consistent with the usages of the second type, and Matt 11:25-27 may be compared with Test. Job 40:2 (see also Tob 13:4)"; cf. the identical statement: Chilton, “God as 'Father"' 161, 166-167. At this point, it is sufficient to recall the analyses in Jeremias, Neutestamentliche Theologie, 65-66.

Flis, "Struktura i treść," 22-27; cf. Schwarz, "Matthäus VI.9-13/Lukas XI.2-4," 233-234; cf. Zimmermann, Die Namen des Vaters, 84-87.

39 The composition, tradition and redaction of "Our Father" have been widely discussed. See Jeremias, "The Lord's Prayer," 141-146; cf. Paciorek, Q - Ewangelia Galilejska, 295-296; Flis, "Struktura i treść," 28-32; Rosik, "Judaistyczne tło Modlitwy Pańskiej," 114-118; Dunn, Jesus Remembered, 718. 
ground living outside Palestine. At this point, the theological message of the texts in which the invocation appears is of less importance; the apostle illuminates the mys-

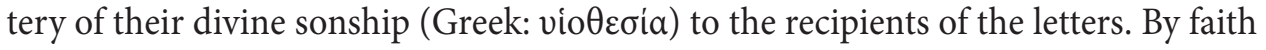
and incorporation in Jesus Christ, believers become children of God, crying "Abba! Father!" 40 The important fact is that the Spirit of Christ is the source and mediator of the believers' adoption to sonship as we can read in Galatians: "And because you are children, God has sent the Spirit of his Son into our hearts, crying, 'Abba! Father!" (Gal 4:6; cf. Rom 8:15). Christians, crying Abba to God, did not create this invocation but imitated Jesus Christ whose Spirit cried to God as Father. Jesus Christ is the one who was the first to address God "Abba, Father" (Mark 14:36), not only in its theological but also historical dimension. ${ }^{41}$

The second element complements our conclusion, and at the same time has again an irresistible evidential value. Since it is necessary to answer the broader question about the origin and sources of the Pauline theology of God's fatherhood, this peculiar "patrocentrism" 42 present in his letters. The divine filiation of Jesus Christ and

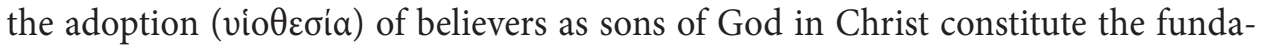
mental theological ideas of the Apostle to the Nations. The characteristic address to God "our Father" can be commonly found in Paul's letters, in the liturgical formulas, professions of faith and prayers originated from the Christian tradition, most often

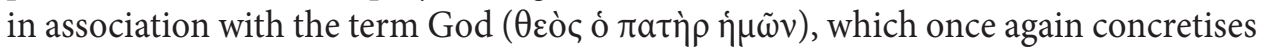
the theological and existential meaning of the formula. Suffice to say that the prescripts of Paul's letters as well as the greetings and statistical data that they include confirm the permanent place of the idea of God's fatherhood in Paul's letters. ${ }^{43}$ We

40 Cf. Rom 8:15.23; 9:4; Gal 4:5; Eph 1:5. For the theme of the adoption as sons in Saint Paul's theology see Obeng, "Abba, Father," 363-366; Scott, Adoption as Sons of God, 149-186.

41 Dunn, Jesus Remembered, 716: "The most obvious conclusion to draw from all this is that the Abba prayer was so cherished among the first believers precisely because it was Jesus' own prayer form. It was precisely because it was his way of praying that their use of it served as assurance that they shared in his sonship"; so Dunn, The Theology of Paul, 193: "In other words, it was probably Jesus' own practice which stamped the Aramaic term with its character as a quasi-sacred prayer form. And it was probably the memory of Jesus thus hallowing the address which ensured that the Aramaic term was preserved into the Greek-speaking churches." Cf. also Scott, Adoption as Sons of God, 184: "[...] there can be no doubt that aßßa in Gal. 4:6 recalls Jesus' own address of God as Father"; so Thompson, The Promise of the Father,

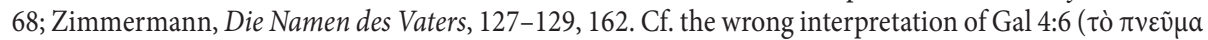

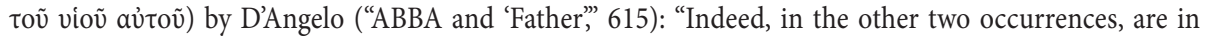
the letters of Paul, $a b b a$ is explicitly attributed not to Jesus but to spirit in the early Christian community."

42 Jankowski, "Modlitwa apostolska," 31, says that this patrocentrism can be seen in the addresses (prescripts) and hymns of praise (eulogies); whenever Paul generally spoke about prayers to God he meant "Father of our Lord Jesus Christ." Cf. Langkammer, "Bóg jako Ojciec," 155-168, writing about Paul's "patrotheology"; see also Łabuda, "Paweł jako ojciec i Bóg jako «Abba, Ojciec»", 177-189.

43 See Rom 1:7-8; 1 Cor 1:3-4; 2 Cor 1:2; Gal 1:3-4; Phil 1:2-3; 1 Thess 1:3; 3:11.13; 2 Thess 1:2; 2:16; Phlm 3-4; cf. Col 1:2; Eph 1:2. In the Pauline letters, out of the 63 usages of the term ratń as many as 41 refer to God the Father. See the discussion of the vocabulary in Schrenk - Quell, "זatŕp," 1007-1013; cf. Zimmermann, Die Namen des Vaters, 129-139, 162. 
are open, or even obliged to ask whether it was Saul, certainly knowing the Law and the Prophets and other religious writings of the Jews, who developed the theological thought about the divine fatherhood of Jesus, or whether he drew his theological inspiration from Jesus of Nazareth and the apostolic tradition, which is more likely. The connection between Jesus' earlier teaching about God as Father and the theological idea of Jesus' divine sonship and the adoption disciples as sons, as found in Paul's letters, seem obvious and undeniable. ${ }^{44}$

Likewise, we should interpret the data contained in the later canonical Gospels, in which the theological idea of divine fatherhood or divine sonship had an important place. A good example is primarily Matthew who put focus on the collocation "the Father who is in heaven" (in several variants), thus, inter alia, ordering the Sermon on the Mount (Mt 5-7). The term $\pi \alpha \tau \eta \dot{\rho}$ most frequently appears with an object:

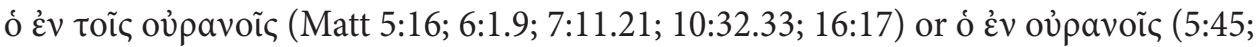
$18: 10.14 .19)$ as well as ó oủpávioৎ $(5: 48 ; 6: 14.26 .32 ; 15: 13 ; 18: 35 ; 23: 9)$. These collocations do not necessarily point to the Jewish community in Matthew (third Sitz im Leben), but they rather seem to reflect the early way of speaking about God in the circles of primitive Christianity (Sondergut Matthew). The meaning of the collocation is completed by Jesus' teaching on the Mount; he explains the idea and content of God's fatherhood to his listeners (Matt 5:1-2): forgiveness (Matt 6:14-15), protection (Matt 6:25-34), goodness (Matt 7:7-11) or will (Matt 7:21). ${ }^{45}$ One should also recollect the third Evangelist who transmitted his own material, which the other Evangelists were not familiar with (Sondergut Luke), including the parable of the prodigal son and merciful father (Luke 15:11-32) or the words of Jesus dying on the cross (Luke 23:34.46). ${ }^{46}$

The culmination of the development of the NT idea concerning God as Father is the fourth Gospel, which is unambiguously proved by the statistical data and first of all, by the theological contents of the terms "Father" and "Son" in their mutual relation. ${ }^{47}$ There are many Johannine texts that illustrate the bond between the Son and the Father. The key text can be found in chapter five of the fourth Gospel (John 5:19-30). It presents the intimate relationship between the Father and the Son, a relationship of love and full trust, and shows the work that the Father entrusted to

44 Dunn, The Theology of Paul, 193; cf. Dunn, Jesus Remembered, 348; see also Thompson, The Promise of the Father, 63-65.

45 The term $\pi a \tau \eta \dot{\rho}$ occurs 63 times in the first Gospel, out of which 45 refer to God as the Father of Jesus

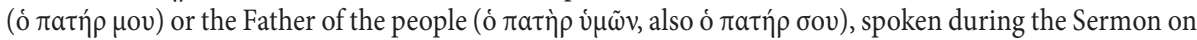
the Mount - 17 times, out of which 10 times in its central part - Matt 6:1-18. See Jeremias, "Abba," 34-36;

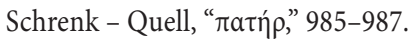

46 Out of the 56 passages in the third Gospel where the term $\pi \alpha \tau$ t $\rho$ appears only in 17 cases it refers to God the Father; $\pi \alpha \tau i n \rho$ also appears 12 times in the parable of the prodigal son.

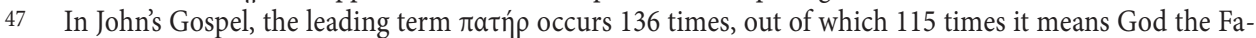

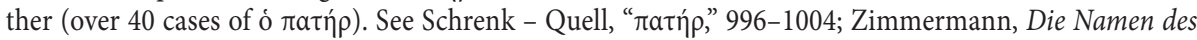
Vaters, 75, 115-125, 164; cf. Wróbel, “Obraz Boga Ojca," 11-38; Wróbel, "Jezus Janowy," 191-203. 
the Son. Similar content can be seen in the seventeenth chapter of the Gospel, Jesus' priestly prayer (John 17:1-26). The Father is the One who sent (o $\pi \varepsilon \dot{\varepsilon} \psi a \varsigma)$ the Son

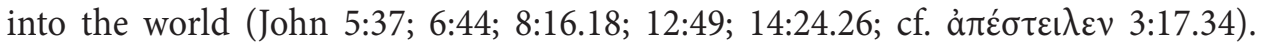
The Father is the One who gave everything to the Son: he gave him words and works to be done $(5: 36 ; 17: 8)$; he also gave him believers $(6: 37.39 ; 10: 29 ; 17: 2.6)$, authority (17:2), name (17:11-12) and glory (17:22-24). It is also worth recalling the words of Jesus about the full knowledge of the Son and the Father (John 10:15; cf. Matt 11:27; Luke 10:22) or the concise but deeply meaningful summary of his words: "The Father and I are one" (John 10:30).

The remarkable depiction of Jesus' relationship with God: Father - Son is rooted in the earliest apostolic tradition and attested by all the New Testament sources, also those that have not been included in this study (Ephesians, 1 Peter, Revelation). The theological idea of God as Father originated in the teaching of the historical Jesus (Q, Mark), and thanks to the redactional work of early Christian theologians, it was developed and assumed a diverse form. Accordingly, in the New Testament writings, we can speak of the presence of at least three complementary theologies of God's fatherhood: "God, our Father" (Paul), "Father who is in heaven" (Matthew) and "Father - Son" (John).

\section{Conclusion}

The main purpose of resuming the topic of God's intitulation as Abba was to show that without Jesus of Nazareth and his teaching the extraordinary development of the theological thought about God's fatherhood recorded in the New Testament writings would have been unthinkable.

The conducted research and analyses allow us to formulate three conclusions, which would be difficult to refute.

(1) The debaters agree that the theme of God as Father was known in the biblical tradition, although it was not its important and dominant element. In the Hebrew Bible, the term אב refers to God only 15 times out of a total of 1,213 cases. A probable reason for that was that the religious environment of the Old Testament and pagan beliefs were dominated by various mythical stories about the deities' divine parents (theogonies), the world's divine parents (cosmogonies) and also divine parents of the human race. Therefore, the biblical authors' caution in formulating theses is not surprising at all, as it is understandable to view God's parenthood of Israel in terms of choice, establishment, or adoption, as well as to note the widespread use of comparisons or metaphors. In the period preceding the rise of Christianity, the situation did not change significantly. The preserved textual witnesses written in Hebrew, Aramaic 
and Greek are sparse although they cover a significant period: from the fourth-third centuries $\mathrm{BC}$ to the beginning of the second century AD. Nevertheless, one should note a certain deepening of the theological idea of God's fatherhood. For example, it was recognised that only those who keep the Law are children of God or that the majesty and splendour of God still evoked believers' respect. Only a few passages have the form of a collective or individual prayer addressed to God as Father; later this practice was considerably changed.

(2) The depicted historical-religious situation must evoke questions about the sources of and reasons for the novelty and uniqueness of God's fatherhood in nascent Christianity, which was confirmed in the NT writings. This religious phenomenon was exceptional and one of a kind. In an extremely short period of time, from about $50 \mathrm{AD}$ to the beginning of the second century, the New Testament used the term $\pi \alpha \tau$ in $\rho$ in relation to God in a consistently theological way. Out of the 413 occurrences of the term in the New Testament, as many as 255 convey the meaning: o $\pi a \tau \eta \dot{\rho}$ - God the Father. ${ }^{48}$ The early Christian authors developed and deepened the understanding and content of God's fatherhood in two dimensions: divine son-

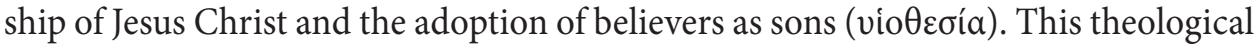
content was not found in the Jewish religious literature of that time. Hence, here we need to apply an alternative or choice. The phenomenon should be ascribed to an indefinite number of anonymous authors, who in geographically different places but similar periods as well as independently of one another, worked out the New Testament theology of God's fatherhood. ${ }^{49}$ Another solution would be that the source of the inspiration of Christian communities, as well as their literary and theological representatives, was the historical Jesus of Nazareth, in whose divinity they believed. In the second case, this is the repetition and confirmation of Jeremias's position, which he developed on the basis of detailed diachronic analyses.

(3) All the literary texts-witnesses preserved in the New Testament and all rational premises point to Jesus of Nazareth as the source and starting point of the New Testament theology of God the Father. Jesus himself addressed God as Father, which is confirmed in the canonical Gospels. Further, he might have used the Aramaic word Abba (Mark 14:36; Gal 4:6). Did Jesus assume such an attitude of prayer to continue the existing models, which indeed were sparse? ${ }^{50}$ Or was Jesus who invoked

48 Slightly different statistical data are given in Zimmermann, Die Namen des Vaters, 74; it is worth referring to her apt comment: "Патท́ $\rho$ wird Gott in den ntl. Schriften 261 mal genannt. Das ist gegenüber nicht einmal 20 Belegen aus dem AT und ca. 50 Belegen aus frühjüdischen Texten auch angesichts des Umfangs der Schriften beachtlich."

49 This is the direction of the proposal adopted by D'Angelo ("ABBA and 'Father," esp. 615). It should be remembered that Mark, Paul and other NT authors are not creators but only witnesses to and transmitters of the existing traditions; see Thompson, The Promise of the Father, 63.

50 Philonenko, "De la 'Prière de Jésus," 136: "La formule du Psaume 89,27 a donc été utilisée comme invocation dans des prières hébraïques et rien ne s'oppose à ce que Jésus ait fait de même dans ses prières araméennes, en disant à Dieu abba." 
God as Abba the First and Only One who did that, and if so, in what sense? ${ }^{51}$ Little is known about the general and religious education of Jesus, and the New Testament is the main source of our knowledge about him. In the apostles' memory, Jesus was recorded as the One for whom God was his and our Father (John 20:17). When the apostles were passing on this truth in Greek to the next generations, Jesus' word for "father" was the Greek $\pi \alpha \tau \eta \dot{\rho} \rho$. On the other hand, the Son of Mary and Joseph was a Galilean and spoke Aramaic, which was commonly used there; the fact was clearly recorded in the Gospels (Mark 5:41; 7:34; Matt 5:22; 6:24; 27:6). Likewise, he - the Messiah and the Son of God - used the Aramaic Abba in addressing his Father in heaven.

Conclusively, it should be stated that Jeremias's study remains valid in its basic theses. "Abba, Father," the cry of the historical Jesus, was a brief and, at the same time, fullest expression of his filial relationship with the Father. ${ }^{52}$

\section{Bibliography}

Barr, J., “'ABBĀ isn't 'DADDY”, The Journal of Theological Studies 39 (1988) 28-46.

Beyer, K., Die aramäischen Texte vom Toten Meer (Göttingen: Vandenhoeck \& Ruprecht 1984). Chilton, B., "Abba," Encyclopedia of the Bible and Its Reception. I. Aaron - Aniconism (eds. H.-J. Klauck et al.) (Berlin - New York: de Gruyter 2009) 40-43, DOI: https://doi.org/10.1515/ EBR.abba [access 20.04.2020].

Chilton, B., "God as 'Father' in the Targumim, in Non-Canonical Literatures of Early Judaism and Primitive Christianity, and in Matthew," The Pseudepigrapha and the Early Biblical Interpretation (eds. J.H. Charlesworth - C.A. Evans) (Journal for the Study of the Pseudepigrapha. Supplement Series 14; Sheffield: Sheffield Academic Press 1993) 151-169.

Chrostowski, W., "Bóg jako Ojciec w judaizmie," «Ty, Panie, jesteś naszym Ojcem» (Iz 64,7). Biblia o Bogu Ojcu (eds. F. Mickiewicz - J. Warzecha) (Rozprawy i Studia Biblijne 5; Warszawa: Vocatio 1999) 205-215.

D'Angelo, M.R., "ABBA and 'Father': Imperial Theology and the Jesus Tradition," Journal of Biblical Literature 111 (1992) 611-630.

D’Angelo, M.R., "Theology in Mark and Q: Abba and 'Father' in Context," Harvard Theological Review 85 (1992) 149-174.

Dalman, G., The Words of Jesus Considered in the Light of Post-Biblical Jewish Writings and the Aramaic Language, Authorised English version (trans. D.M. Kay) (Edinburgh: Clark 1902).

51 As Ternyák (“'Abba’ nel pensiero," 60) aptly concluded: "Abbà è una parola che non si può comprendere senza il suo corrispondente: Figlio mio. Essi sono due concetti strettamente connesi che si presuppongono a vicenda."

52 Cf. Hengel, "Abba, Maranatha, Hosanna," 171: "Trotz vielerlei, häufig unsachlicher Kritik (und mancher Einseitigkeiten) bleibt die Studie von J. Jeremias grundlegend”; cf. Dunn, Jesus Remembered, 716-717 and note 47. 
Doering, L., "God as Father in Texts from Qumran," The Divine Father. Religious and Philosophical Concepts of Divine Parenthood in Antiquity (eds. F. Albrecht - R. Feldmeier) (Themes in Biblical Narrative 18; Leiden: Brill 2014) 107-135.

Dunn, J.D.G., Jesus Remembered (Christianity in the Making 1; Grand Rapids, MI: Eerdmans 2003).

Dunn, J.D.G., The Theology of Paul the Apostle (Grand Rapids, MI: Eerdmans 2006).

Fabry, H.-J., "אָ 'āb," Theologisches Wörterbuch zu den Qumrantexten (eds. H.-J. Fabry U. Dahmen) (Stuttgart: Kohlhammer 2011) I, 1-9.

Fitzmyer, J.A., "ABBA and Jesus' Relation to God," A cause de l'Évangile. Mélanges offertes à Dom Jacques Dupont (Lectio Divina 123; Paris: Cerf 1985) 14-38.

Flis, J., "Struktura i treść krótszej wersji modlitwy Ojcze nasz (Łk 11,2b-4)," Colloquia Theologica Ottoniana 2 (2013) 21-41.

Gnadt, M.S., '“Abba isn't Daddy.' Aspekte einer feministisch-befreiungstheologischen Revision des 'Abba Jesu"' Von der Wurzel getragen. Christlich-Feministische Exegese in Auseinandersetzung mit Antijudaismus (eds. L. Schottroff - M.-Th. Wacker) (Biblical Interpretation Series 17; Leiden - New York - Köln: Brill 1996) 115-131.

Grelot, P., “Une mention inaperçue de «ABBA» dans le Testament araméen de Lévi," Semitica 33 (1983) 101-108.

Hengel, M., "Abba, Maranatha, Hosanna und die Anfänge der Christologie," Denkwürdiges Geheimnis. Beiträge zur Gotteslehre. Festschrift für E. Jüngel zum Geburtstag 70 (eds. I.U. Dalferth - J. Fischer - H.-P. Großhans) (Tübingen: Mohr Siebeck 2004) 145-183.

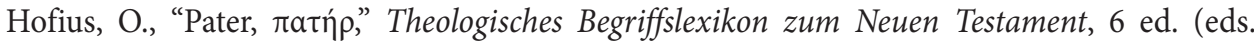
L. Coenen - E. Beyreuther - H. Bietenhard) (Wuppertal: Brockhaus 1986) II, 1245-1246.

Jankowski, A., "Modlitwa apostolska według św. Pawła," Ruch Biblijny i Liturgiczny 56/1 (2003) $27-32$.

Jeremias, J., “Abba," Abba. Studien zur neutestamentlichen Theologie und Zeitgeschichte (ed. J. Jeremias) (Göttingen: Vandenhoeck \& Ruprecht 1966) 15-67.

Jeremias, J., “The Lord's Prayer in Modern Research,” Expository Times 71 (1959-1960) 141-146. Jeremias, J., Neutestamentliche Theologie. I. Die Verkündigung Jesu, 4 ed. (Gütersloh: Mohn 1988). Keener, C., "Luke-Acts and the Historical Jesus," Jesus Research. New Methodologies and Perceptions. The Second Princeton-Prague Symposium on Jesus Research, Princeton 2007 (eds. J.H. Charlesworth - B. Rhea) (Princeton-Prague Symposia Series on the Historical Jesus 2; Grand Rapids, MI - Cambridge: Eerdmans 2014) 600-623.

Kręcidło, J., "Ewangelie jako prawdziwe świadectwo Słowa Wcielonego," The Biblical Annals 9/1 (2019) 177-190.

Kudasiewicz, J., “Jezus Chrystus Pośrednikiem objawienia," Ateneum Kapłańskie 84/3 (1992) 432-447.

Langkammer, H., "Bóg jako Ojciec w Listach św. Pawła. Próba syntezy patroteologii Pawłowej," Abba Ojcze! (ed. A.J. Nowak) (Homo Meditans 21; Lublin: TN KUL 2000) 155-168.

Łabuda, P., "Paweł jako ojciec i Bóg jako «Abba, Ojciec»," Verbum Vitae 20 (2011) 171-190.

Mitchell, D.C., "A Dying and Rising Josephite Messiah in 4Q372," Journal for the Study of the Pseudepigrapha 18/3 (2009) 181-205.

Obeng, E.A., "Abba, Father: The Prayer of the Sons of God," The Expository Times 99 (1988) 363-366. 
Paciorek, A., Q - Ewangelia Galilejska (Lublin: TN KUL 2001).

Philonenko, M., 'De la 'Prière de Jésus' au 'Notre Père' (Abba; targoum du Psaume 89,27; 4Q369,1,2, 1-12; Luc 11,2)," Revue d'Histoire et de Philosophie Religieuses 77 (1997) 133-140.

Pontificia Commissione Biblica, Ispirazione e verità della Sacra Scrittura. La parola che viene da Dio e parla di Dio per salvare il mondo (Roma: Libreria Editrice Vaticana 2014).

Puech, É., "Dieu le Père dans les écrits péritestamentaires et les manuscrits de la Mer Morte," Revue de Qumrân 20 (2001) 287-310.

Ringgren, H., "אָ 'ābh," Theological Dictionary of the Old Testament (Grand Rapids, MI: Eerdmans 1977) I, 1-19.

Rosik, M., "Judaistyczne tło Modlitwy Pańskiej (Mt 6,9-13) w świetle idei ojcostwa Bożego w Kazaniu na Górze," Verbum Vitae 20 (2011) 115-137.

Ruckstuhl, E., "Abba, Vater! Überlegungen zum Stand der Frage," Freiburger Zeitschrift für Philosophie und Theologie 41 (1994) 515-525.

Rupprecht, K., "Zu Herkunft und Alter der Vater-Anrede Gottes im Gebet des vorchristlichen Judentums," Die Hebräische Bibel und ihre zweifache Nachgeschichte. Festschrift für Rolf Rendtorff zum 65. Geburtstag (Neukirchen-Vluyn: Neukirchener 1990) 347-355.

Schelbert, G., Abba Vater. Der literarische Befund vom Altaramäischen bis zu den späten Midrasch- und Haggada-Werken in Auseinandersetzung mit den Thesen von Joachim Jeremias (Göttingen: Vandenhoeck \& Ruprecht 2011).

Schelbert, G., "Abba, Vater! Stand der Frage," Freiburger Zeitschrift für Philosophie und Theologie 40 (1993) 259-281.

Schelbert, G., "Sprachgeschichtliches zu Abba," Mélanges Dominique Barthélemy. Études bibliques offertes à l'occasion de son 60e anniversaire (Orbis Biblicus et Orientalis 38; Fribourg - Göttingen: Vandenhoeck \& Ruprecht 1981) 395-447.

Schenker, A., "Gott als Vater - Söhne Gottes. Ein vernachlässigter Aspekt einer biblischen Metapher," Freiburger Zeitschrift für Philosophie und Theologie 25 (1978) 3-55.

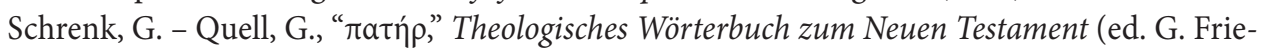
drich) (Stuttgart: Kohlhammer 1966) V, 945-1022

Schuller, E.M., “4Q372 1. A Text about Joseph,” Revue de Qumrân 14 (1990) 349-376.

Schuller, E.M., "The Psalm of 4Q372 1 Within the Context of Second Temple Prayer," Catholic Biblical Quarterly 54 (1992) 67-79.

Schwarz, G., "Matthäus VI.9-13/Lukas XI.2-4. Emendation und Rückübersetzung," New Testament Studies 15 (1969) 233-247.

Scott, J.M., Adoption as Sons of God. An Exegetical Investigation into the Background of Yiothesia in the Pauline Corpus (Wissenschaftliche Untersuchungen zum Neuen Testament 2/48; Tübingen: Mohr Siebeck 1992).

Sim, D.C., "The Family of Jesus and the Disciples of Jesus in Paul and Mark. Taking Sides in the Early Church's Factional Dispute," Paul and Mark. Comparative Essays. I. Two Authors at the Beginnings of Christianity (eds. O. Wischmeyer - D.C. Sim - I.J. Elmer) (Berlin Boston, MA: De Gruyter 2014) 73-99.

Spittler, R.P., “Testament of Job,” The Old Testament Pseudepigrapha (ed. J.H. Charlesworth) (Garden City, NY: Doubleday 1983) I, 829-868. 
Strotmann, A., "Mein Vater bist Du!" (Sir 51,10). Zur Bedeutung der Vaterschaft Gottes in kanonischen und nichtkanonischen frühjüdischen Schriften (Frankfurter theologische Studien 39; Frankfurt am Main: Knecht 1991).

Szymik, S., "Biblijna idea Boga jako Ojca na tle religijnych wierzeń starożytnego Bliskiego Wschodu," Zeszyty Naukowe KUL 44 (2001) 3-26.

Szymik, S., "Biblijno-religijny kontekst Jezusowej intytulacji Boga jako 'Abba"' "To urzeczywistniajcie w Kościele, co w Chrystusie Jezusie” (Flp 2,5). Księga pamiątkowa dla Księdza Profesora Jana Flisa $w$ 70. rocznice urodzin (eds. P. Goniszewski - C. Korzec) (Szczecin: Volumina.pl 2015) 645-656.

Ternyák, C., “'Abba’ nel pensiero di Joachim Jeremias," Folia Theologica [Budapest] 2 (1991) 29-60. Theobald, M., "Die Passion Jesu bei Paulus und Markus," Paul and Mark. Comparative Essays. I. Two Authors at the Beginnings of Christianity (eds. O. Wischmeyer - D.C. Sim I.J. Elmer) (Berlin - Boston, MA: De Gruyter 2014) 243-282.

Theophilos, M.P., “The Roman Connection: Paul and Mark," Paul and Mark. Comparative Essays. I. Two Authors at the Beginnings of Christianity (eds. O. Wischmeyer - D.C. Sim I.J. Elmer) (Beihefte zur Zeitschrift für die neutestamentliche Wissenschaft 198; Berlin Boston, MA: De Gruyter 2014) 45-71.

Thompson, M., The Promise of the Father. Jesus and God in the New Testament (Louisville, KY: Westminster John Knox Press 2000).

Wilk, F., “"Vater...». Zur Bedeutung der Anrede Gottes als Vater in den Gebeten der Jesusüberlieferung," The Divine Father. Religious and Philosophical Concepts of Divine Parenthood in Antiquity (eds. F. Albrecht - R. Feldmeier) (Themes in Biblical Narrative 18; Leiden: Brill 2014) 201-231.

Wojciechowski, M., Apokryfy z Biblii greckiej (Rozprawy i Studia Biblijne 8; Warszawa: Vocatio 2001).

Wróbel, M.S., “Jezus Janowy jako objawiciel oblicza Ojca," Verbum Vitae 20 (2011) 191-203.

Wróbel, M.S., "Obraz Boga Ojca," Teologia Nowego Testamentu. Dzieło Janowe (ed. M. Rosik) (Wrocław: TUM 2008) II, 11-38.

Zimmermann, Ch. Die Namen des Vaters. Studien zu ausgewählten neutestamentlichen Gottesbezeichnungen vor ihrem frühjüdischen und paganen Sprachhorizont (Biblical Studies \& Religious Studies 69; Leiden: Brill 2007). 